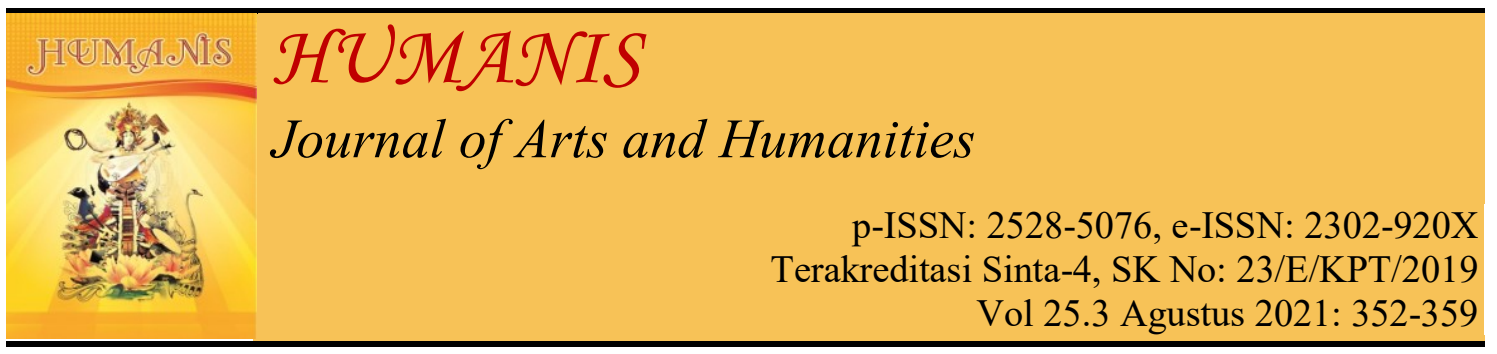

\title{
Kritik Sosial pada Kumpulan Cerpen Aud Kelor Karya Carma Citrawati Analisis Sosiologi Sastra
}

\author{
Ni Kadek Ayu Sulastri, Putu Sutama \\ Universitas Udayana, Denpasar, Bali, Indonesia \\ Email korespondensi: ayusulastri72@gmail.com, sutama_udayana@yahoo.com
}

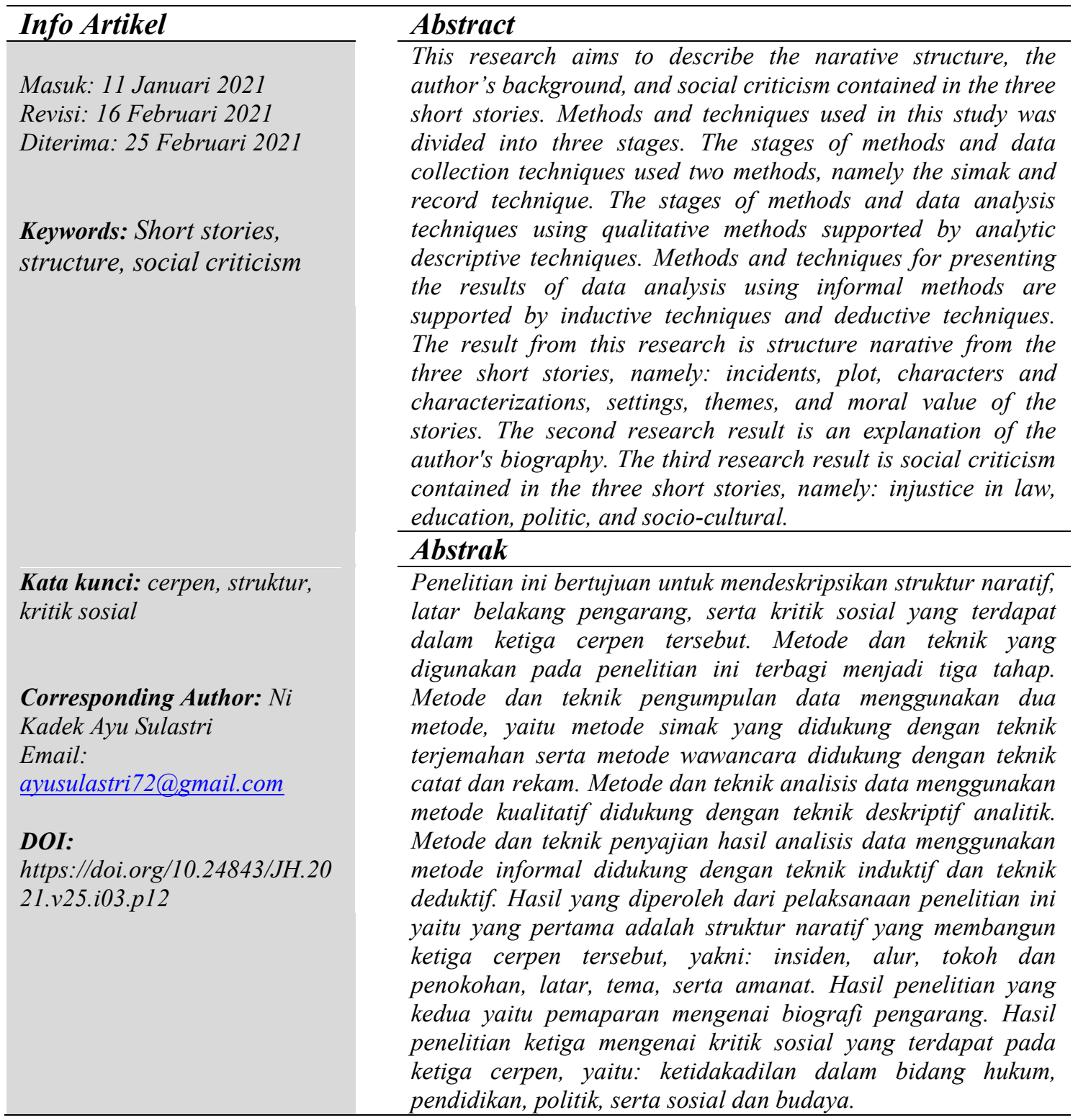

PENDAHULUAN 
Kesusastraan merupakan media yang digunakan untuk menyalurkan ide maupun gagasan yang dimiliki oleh seorang pengarang kepada pembacanya. Pada kesusastraan terdapat nilai-nilai kehidupan yang bisa dijadikan pedoman oleh masyarakat. Kesusastraan Bali merupakan salah satu kebudayaan yang ada di Bali, sebagai hasil dari warisan yang diturunkan oleh para leluhur masyarakat Bali. Berdasarkan pada jaman karya sastra tersebut diciptakan, Kesusastraan Bali terbagi menjadi dua jenis, yaitu Sastra Bali Kekunaan (tradisional) dan Sastra Bali Anyar (modern) (Suardiana, 2011: 1).

Salah satu bentuk dari Sastra Bali Anyar (modern) adalah cerpen. Cerpen menjadi media yang paling tepat untuk menggambarkan suatu kondisi yang ada pada suatu lingkungan masyarakat (Ratna, 2011: 91). Keberadaan cerpen berbahasa Bali bermula pada tahun 1900an (Putra, 2011: 9). Karya sastra dalam bentuk cerpen berkembang begitu pesat dan semakin ramai di kalangan pengarang Bali. Salah satu pengarang yang produktif dalam menciptakan cerpen adalah I Dewa Ayu Carma Citrawati. Buku kumpulan cerpen terbaru karangan beliau berjudul Aud Kelor. Buku tersebut merupakan bahan kajian pada penelitian ini.

Terdapat beberapa hal menarik yang membuat peneliti menjadikan buku ini sebagai objek penelitian. Pertama, peneliti tertarik dengan buku ini semenjak buku ini diterbitkan. Buku ini memiliki judul yang menarik serta tampilan buku yang mengesankan. Kedua, setelah membaca buku ini, peneliti merasa terkesan dengan cara pengarang menyampaikan cerita pada setiap cerpen. Ketiga, peneliti menemukan kejadian maupun fenomena sosial yang terjadi di masyarakat negara ini. Peneliti mengambil tiga buah cerpen untuk diteliti, yaitu cerpen yang berjudul
Wayan Kelor, Siaappp Presiden, dan Keneh Pasih.

Ketiga judul tersebut dijadikan bahan kajian karena topik cerita yang diangkat sangat menarik yaitu mengenai fenomena sosial yang terjadi di masyarakat. Pada ketiga cerpen tersebut, pengarang juga menyampaikan kritik mengenai fenomena sosial yang diceritakan. Sedangkan, pada sepuluh cerpen lainnya, pengarang hanya membahas fenomena sosial yang ada di masyarakat secara umum dan tidak terdapat kritik yang ingin disampaikan oleh pengarang. Ketiga cerpen tersebut juga memiliki benang merah yaitu membahas mengenai ketidakadilan, yang digambarkan dengan adanya suatu pihak yang dirugikan.

Pada judul yang pertama yaitu Wayan Kelor menceritakan mengenai Wayan Kelor yang tengah diadili oleh Sang Suratma atas dosa yang telah diperbuat ketika hidup. Berdasarkan cerita yang ada, cerpen ini membahas mengenai ketidakadilan hukum yaitu pemberian keputusan yang tidak tepat pada saat pelaksanaan pengadilan. Pada judul yang kedua yaitu Siaappp Presiden menceritakan mengenai ketidakadilan dalam suatu pemilihan pemimpin. Diceritakan bahwa I Kelor mencalonkan diri menjadi presiden. Ia melakukan segala cara untuk mengalahkan calon presiden yang kedua yaitu Pak Joko. I Kelor dan Mangku Kelor mencuri perhatian masyarakat dengan menyuap masyarakat dalam bentuk uang serta pengobatan gratis. Mereka melakukan suap agar masyarakat mau memilih mereka. Pada judul yang ketiga yaitu Keneh Pasih menceritakan ketidakadilan dalam mengeluarkan pendapat. Diceritakan bahwa tokoh Wayan Adi berusaha keras untuk menolak adanya reklamasi di laut yang sangat dicintainya. Cerita yang ada pada cerpen ini tentunya sangat jelas menyinggung suatu fenomena yang terjadi di masyarakat Bali 
yaitu adanya rencana reklamasi Teluk Benoa.

Peneliti mengkaji ketiga cerpen tersebut dengan menggunakan teori sosiologi sastra. Sosiologi sastra merupakan penggambaran bentuk karya sastra yang memusatkan perhatiannya terhadap fenomena sosial yang ada di masyarakat (Glikberg, 1967: 75). Sesuai dengan isi dari buku kumpulan cerpen Aud Kelor yang mengangkat mengenai fenomena di masyarakat pada saat ini. Fenomena-fenomena yang ditanggapi dengan kritik sosial tersebut sangat menarik untuk dikaji berdasarkan analisis sosiologi sastra, karena adanya pengaruh timbal balik antara masyarakat dengan suatu karya sastra. (Burn, 1973: 31). Terdapat tiga hal yang dikaji oleh peneliti yaitu, yang pertama adalah struktur dari karya sastra tersebut, yang kedua adalah latar belakang pengarang dalam menciptakan karya sastra tersebut dan yang ketiga kritik sosial yang terdapat di dalamnya.

\section{METODE}

Penelitian ini menggunakan sumber data primer yaitu data yang didapat secara langsung dari suatu objek tertentu, baik lisan maupun tulisan. Data yang dianalisis pada penelitian ini adalah kumpulan cerpen Aud Kelor karya dari Carma Citrawati. Pada kumpulan cerpen tersebut terdapat 13 buah judul cerpen. Dari keseluruhan judul tersebut, terdapat tiga buah cerpen yang dikaji yaitu Wayan Kelor, Siaappp Presiden, dan Keneh Pasih.

Metode merupakan gambaran yang sederhana dari suatu masalah yang berfungsi untuk mempermudah pemahaman (Sudaryanto, 1993: 2). Teknik merupakan alat yang digunakan untuk memecahkan suatu permasalah dan dapat dilihat secara nyata (Ratna, 2008: 37). Metode dan teknik penelitian yang digunakan pada penelitian ini terbagi menjadi tiga tahap, yaitu tahap pengumpulan data, tahap analisis data, serta tahap penyajian hasil analisis data.

Pada tahap pengumpulan data terdapat dua metode yang digunakan yaitu metode simak dan metode wawancara. Metode simak dilakukan dengan cara membaca objek kajian secara berulang sehingga lebih dipahami (Sudaryanto, 1993: 2). Metode tersebut didukung dengan menggunakan teknik terjemahan, baik terjemahan yang harfiah, maupun terjemahan yang idiomatis. Metode yang kedua adalah metode wawancara yaitu mewawancarai pengarang buku Aud Kelor. Metode ini didukung dengan menggunakan teknik catat dan teknik rekam untuk mengingat informasi penting yang disampaikan.

Tahap analisis data menggunakan metode kualitatif yaitu mengkaji datadata yang bersifat ilmiah. Metode ini dapat mengaitkan gejala sosial yang ada dengan tepat (Ratna, 2008: 47). Metode tersebut didukung oleh teknik deskriptif analisis, yaitu data yang didapat dianalisis dengan cara dijabarkan atau diuraikan sehingga data bisa dijelaskan dengan tepat (Ratna, 2008: 53).

Tahap penyajian hasil analisis data menggunakan metode informal, yaitu penyajian hasil penelitian melalui uraian kata-kata maupun deskripsi (Ratna, 2008: 50). Metode tersebut didukung dengan penggunaan teknik induktif dan teknik deduktif. Teknik induktif merupakan proses pemikiran suatu masalah yang dimulai dari khusus ke umum. Sedangkan, teknik deduktif merupakan proses pemikiran suatu masalah yang dimulai dari prinsip umum ke khusus (Tarigan, 1984: 111-112).

\section{KERANGKA TEORI}

Terdapat beberapa penelitian sebelumnya yang membahas mengenai kritik sosial pada suatu karya sastra. Penelitian ini menggunakan empat kajian 
pustaka, salah satunya yaitu Sukarini (2015) dalam jurnalnya yang berjudul Aspek-Aspek Sosial Cerpen Magibung, Paras Paros, dan Cerpen Sarwagita dalam Kumpulan Cepen Sawelas Satua Bawak Basa Bali. Kajian pustaka tersebut berguna sebagai panduan dan untuk mengetahui posisi penelitian ini.

Teori yang digunakan pada penelitian ini ada dua, yaitu teori struktural dan teori sosiologi sastra. Teori struktural sastra merupakan salah satu teori pendekatan yang diterapkan dalam meneliti suatu karya sastra. Pada teori struktural ini yang ditekankan adalah hubungan antar bagian pada suatu teks. Teori ini pada umumnya berpusat pada teks sastra itu sendiri. Penelitian dilakukan secara objektif dengan menekankan kepada aspek instrinsik pada suatu karya sastra (Endraswara, 2013: 25-51). Unsur instrinsik tersebut merupakan unsur pembangun suatu cerita pada suatu karya sastra. Unsur yang dimaksud yaitu peristiwa, plot, tokoh dan penokohan, latar, tema, serta amanat (Nurgiyantoro, 2010: 23).

Teori struktural yang digunakan adalah teori struktural menurut Nurgiyantoro. Peneliti akan memaparkan struktur naratif yang membangun ketiga cerpen pada buku Aud Kelor yang diteliti. Unsur instrinsik yang akan dipaparkan dari objek yang diteliti yaitu peristiwa, plot, tokoh dan penokohan, latar, tema, serta amanat. Analisis struktural ini akan membuat peneliti lebih memahami karya sastra tersebut dan mendapatkan pemecahan dari masalah mengenai kritik sosial yang terkandung dalam objek penelitian. Analisis struktural ini bertujuan untuk memecahkan permasalahan pertama yaitu mengenai struktur naratif yang membangun cerpen Wayan Kelor, Siaappp Presiden, dan Keneh Pasih.

Sosiologi sastra adalah penelitian yang berpusat pada masalah kehidupan manusia yang terdapat di suatu karya sastra. Sastra sering mengungkapkan permasalahan di kehidupan masyarakat berdasarkan atas imajinasi dan perasaan yang dimiliki oleh pengarang. Perjuangan manusia dalam menjalani hidupnya akan selalu diceritakan pada teks-teks sastra (Endraswara, 2013: 79). Pada sosiologi sastra menurut Wellek dan Warren (Ratna, 2011: 16) terdapat tiga hal utama yang perlu dianalisis, yaitu pengarang, karya sastra, dan pembaca.

Teori sosiologi sastra yang digunakan adalah teori sosiologi sastra menurut Wellek dan Warren. Terdapat dua hal yang akan diteliti dengan menggunakan teori sosiologi sastra tersebut, yaitu pengarang dan karya sastranya. Peneliti akan meneliti latar belakang pengarang dalam menciptakan karya sastra yang diteliti. Informasi dari pengarang akan menjadi informasi tambahan yang mendukung pelaksanaan penelitian ini. Selanjutnya peneliti akan meneliti kritik sosial yang ada pada karya sastra itu sendiri yaitu tiga cerpen pada buku kumpulan cerpen Aud Kelor. Analisis sosiologi sastra ini bertujuan untuk menemukan jawaban dari permasalahan kedua dan ketiga mengenai latar belakang pengarang serta kritik sosial yang terkandung pada cerpen yang dikaji.

\section{HASIL DAN PEMBAHASAN}

\section{Struktur Naratif Kumpulan Cerpen Aud Kelor}

Menurut Nurgiyantoro (2010: 23). unsur instrinsik tersebut merupakan unsur pembangun suatu cerita pada suatu karya sastra. Unsur yang dimaksud meliputi: (1) insiden, (2) plot, (3) tokoh dan penokohan, (4) latar, (5) tema, serta (6) amanat.

Insiden merupakan runtutan peristiwa yang berhubungan dengan adanya perkembangan dari plot dalam 
suatu cerita (Luxemburg, 1984: 150152). Cerpen Wayan Kelor terbagi menjadi enam insiden. Cerpen Siaappp Presiden terbagi menjadi lima insiden. Cerpen Keneh Pasih terbagi menjadi lima insiden. Insiden yang terdapat pada masing-masing cerpen memiliki kaitan antar satu sama lain sehingga membangun suatu struktur cerita pada cerpen-cerpen tersebut.

Menurut Abrams (dalam Nurgiyantoro, 1995: 113-114), plot merupakan struktur peristiwa khususnya pada urutan maupun penyajian yang bertujuan untuk mendapat suatu efek emosional maupun efek artistik lainnya. Alur atau plot yang terdapat dalam ketiga cerpen tersebut terbagi menjadi lima bagian yaitu tahap situation (penyituasian), tahap generating circumstances (pemunculan konflik), tahap rising action (peningkatan konflik), tahap climax (klimaks), dan tahap denoument (penyelesaian). Cerpen Wayan Kelor dan Siaappp Presiden menggunakan alur maju, sedangkan cerpen Keneh Pasih menggunakan alur sorot balik.

Tokoh merupakan peran yang diceritakan dalam suatu karya sastra, sedangkan penokohan merupakan karakter atau sifat yang dimiliki oleh para tokoh. Penokohan merupakan pelukisan mengenai seorang tokoh yang ditampilkan pada sebuah cerita. Oleh karena itu, dalam penokohan terdapat dua aspek yaitu aspek isi dan aspek bentuk (Nurgiyantoro, 1995: 164-166). Tokoh dan penokohan tersebut dibagi menjadi tiga bagian yaitu tokoh utama, tokoh sekunder, dan tokoh pelengkap. Selain itu, pendapat tersebut juga akan dipadukan dengan pendapat dari Sukada yang membagi tokoh dan penokohan menjadi tiga dimensi yaitu dimensi fisikologis, dimensi psikologis, dan dimensi sosiologis.
Tokoh dan penokohan pada cerpen Wayan Kelor yaitu (1) tokoh utama yaitu Wayan Kelor yang bersifat pekerja keras dan penyayang, (2) tokoh sekunder yaitu Sang Suratma yang memiliki rasa ego tinggi dan Luh Sari yang sabar dan pekerja keras (3) tokoh pelengkap yaitu Gede yang selalu sabar. Tokoh dan penokohan pada cerpen Siaappp Presiden yaitu (1) tokoh utama yaitu I Kelor yang licik, dan Mangku Kelor merupakan orang yang sombong dan licik (2) tokoh sekunder yaitu Sang Suratma yang memiliki rasa ego tinggi (3) tokoh pelengkap yaitu istri dari I Kelor yang serakah. Tokoh dan penokohan pada cerpen Keneh Pasih yaitu (1) tokoh utama yaitu Wayan Adi yang tidak mudah putus asa dan rajin (2) tokoh sekunder yaitu Luh Murni yang memiliki rasa ego yang tinggi (3) tokoh pelengkap yaitu I Kelor yang licik, Putu Segara, dan Made Baruna yang tidak hormat kepada orangtuanya.

Latar merupakan segala penjelasan maupun keterangan mengenai waktu, ruang, dan suasana terjadinya kejadian pada suatu cerita (Nurgiyantoro, 1995: 217). Latar tersebut dibagi menjadi tiga jenis yaitu latar waktu, latar tempat, dan latar suasana. Pada cerpen Wayan Kelor, latar waktu yang digunakan adalah tengah hari dan petang hari. Latar tempatnya yaitu di gubuk, rumah Wayan Kelor, kandang ayam, ujung timur laut desa, dan jurang. Sedangkan latar suasananya yaitu suasana marah dan suasana sedih. Pada cerpen Siaappp Presiden, latar waktu yang digunakan malam hari, pagi hari, dan sore hari. Latar tempatnya yaitu di kamar villa dan di langit. Sedangkan latar suasana dari cerpen ini adalah suasana senang dan suasana bimbang atau kebingungan. Pada cerpen Keneh Pasih, latar waktu yang digunakan adalah satu minggu, setiap malam, lima bulan, dan pagi hari. Latar tempatnya yaitu di desa tempat Wayan 
Adi tinggal dan di rumah sakit. Sedangkan latar suasana dari cerpen ini adalah suasana marah, suasana sedih dan suasana senang.

Tema merupakan dasar cerita maupun gagasan umum dari suatu karya sastra. Para pembaca harus bisa menentukan tema yang terdapat dalam suatu karya sastra yang dibaca (Nurgiyantoro, 1995: 70). Tema dari cerpen Wayan Kelor adalah ketidakadilan, khususnya ketidakadilan dalam pemberian hukuman. Tema dari cerpen Siaappp Presiden adalah ketidakadilan, khususnya ketidakadilan dalam bentuk kecurangan pada suatu pemilihan pemimpin. Tema dari cerpen Keneh Pasih adalah ketidakadilan, khususnya ketidakbebasan dalam berpendapat.

Amanat merupakan pesan moral yang ingin disampaikan oleh pengarang kepada pembaca melalui suatu karya sastra. Amanat dapat disampaikan melalui tokoh (Nurgiyantoro, 1995: 322). Amanat dari cerpen Wayan Kelor adalah dalam mengambil suatu keputusan, keputusan tersebut harus dipikirkan dengan baik dan matang agar nanti tidak disesali. Amanat dari cerpen Siaappp Presiden adalah perbuatan curang akan menimbulkan hasil yang buruk. Amanat dari cerpen Keneh Pasih adalah semua orang berhak untuk mengeluarkan pendapat yang dimiliki.

\section{Biografi Pengarang}

Riwayat hidup (biografi) pengarang merupakan penjelasan mengenai kisah hidup seorang pengarang yang ditulis oleh orang lain. Penjelasan mengenai kepribadian dan kehidupan pengarang menjadi suatu metode tertua dan mapan dalam suatu studi sastra (Wellek dan Warren, 1990: 82). Pengarang dari kumpulan cerpen Aud Kelor adalah Carma Citrawati. Beliau adalah seorang pengarang perempuan Bali yang aktif dalam menciptakan karya sastra, baik karya sastra berbahasa Bali, maupun berbahasa Indonesia. Beliau lahir pada tanggal 24 Februari 1990, di Desa Getakan, Kabupaten Klungkung. Beliau telah mengarang beberapa karya sastra berbahasa Bali. Beliau lebih condong mengarang karya sastra dalam bentuk cerpen. Buku kumpulan cerpen Aud Kelor ini tercipta karena terinspirasi dari salah satu karya pengarang Seno Gumira Ajidarma yang berjudul Dunia Sukab. Riwayat hidup dari Carma Citrawati sangat mempengaruhi karya-karya yang diciptakannya.

\section{Kritik Sosial dalam Kumpulan Cerpen Aud Kelor}

Kritik merupakan suatu tanggapan atau kecaman yang disampaikan dengan mempertimbangkan baik buruknya sesuatu yang dikritik tersebut. Kritik sosial merupakan suatu bentuk tanggapan atau respon dari masyarakat yang berguna untuk mengontrol jalannya suatu sistem di masyarakat (Akbar, 1997: 47). Kritik sosial biasanya disampaikan melalui suatu karya sastra. Pengarang biasanya menyampaikan kritik sosial yang dimiliki melalui karya sastra yang diciptakannya.

Kritik sosial yang terdapat pada cerpen Wayan Kelor adalah ketidakadilan dalam bidang hukum yaitu ketidaksesuaian pemberian hukuman, ketidakadilan dalam bidang ekonomi yaitu keberadaan petani yang kurang dipriotaskan, serta ketidakadilan dalam bidang pendidikan yaitu adanya anak yang putus sekolah karena keterbatasan ekonomi. Kritik sosial yang terdapat pada cerpen Siappp Presiden adalah ketidakadilan dalam bidang politik yaitu adanya pejabat yang hanya mementingkan dirinya sendiri, serta adanya perilaku kecurangan dalam bentuk suap. Kritik sosial yang terdapat dalam cerpen Keneh Pasih adalah 
ketidakadilan pada bidang sosial dan budaya yaitu adanya orang yang merusak alam dan ditindasnya orang-orang yang lemah, serta ketidakadilan dalam bidang hukum yaitu pembatasan dalam berpendapat.

Pengarang menyampaikan kritik sosial yang dimilikinya melalui percakapan antartokoh serta latar tempat maupun latar sosial yang ada. Pengarang menunjukkan sisi realitas dan sisi imajinasi yang diciptakannya untuk menyampaikan kritik sosial yang dimiliki. Pengarang menyampaikan kritik sosial tersebut dengan tujuan untuk menyadarkan pembaca agar lebih membuka pola pikirnya terhadap fenomena sosial yang ada.

\section{SIMPULAN}

Berdasarkan pembahasan yang telah dipaparkan tersebut, maka dapat disimpulkan bahwa secara struktur cerpen Wayan Kelor, Siaappp Presiden, dan Keneh Pasih terdiri atas insiden, alur, tokoh dan penokohan, latar, tema, serta amanat. Persamaan dari ketiga cerpen tersebut terlihat pada tokoh yang diciptakan oleh pengarang serta tema yang ada pada ketiga cerita. Perbedaan dari ketiga cerpen tersebut terletak pada alur yang digunakan.

Latar belakang pengarang sangat berpengaruh terhadap cerita serta kritik sosial yang ada dalam ketiga cerpen tersebut. Pengarang pernah menjadi seorang guru serta gemar membaca buku. Selain itu, pengarang juga sering bertemu dengan sastrawan sastra Bali lainnya sehingga membuat karya pengarang menjadi semakin matang. Profesi, ruang lingkup, serta kegemaran dalam membaca membuat pengarang menemukan fakta sosial yang ada di masyarakat. Fakta sosial tersebut kemudian ditanggapi melalui kritik sosial yang disampaikan melalui karyanya.
Secara sosiologis, kritik sosial yang terdapat di dalam ketiga cerpen tersebut yaitu ketidakadilan dalam bidang hukum, bidang pendidikan, bidang politik, serta bidang sosial dan budaya. Pengarang menyampaikan kritik tersebut melalui tokoh serta latar sosial yang ada pada cerita. Kritik sosial tersebut disampaikan secara khusus kepada pembaca dan secara umum kepada masyarakat serta pemerintah. Pengarang sebagian besar tidak menyampaikan solusi atas kritik sosial yang disampaikan melalui ketiga cerpen tersebut. Pengarang hanya menggambarkan fakta sosial yang dikritiknya dan membiarkan pembaca untuk menanggapi lebih lanjut apa yang disampaikannya. Pengarang bertujuan untuk menyadarkan pembaca agar lebih membuka pola pikirnya terhadap fenomena sosial yang ada.

Melalui penelitian ini, peneliti menyarankan kepada pembaca untuk melanjutkan dan semakin mengembangkan penelitian ini. Pembaca dapat mengkaji aspek lain yang terdapat dalam buku Aud Kelor tersebut, seperti mengkaji tokoh dan penokohan serta aspek sosial lainnya yang terkandung dalam buku tersebut. Peneliti juga berharap bahwa dengan adanya penelitian ini, masyarakat akan lebih tertarik untuk membaca karya-karya sastra berbahasa Bali.

\section{DAFTAR PUSTAKA}

Akbar, A. Z. (1997). Kritik Sosial, Pers dan Politik Indonesia" dalam Kritik Sosial dalam Wacana Pembangunan. Yogyakarta: UII Press.

Burn, E. (1973). Sociology Literature and Drama. Australia. Middlesex: Pustaka Jaya. 
Citrawati, Carma. (2019). Aud Kelor. Singaraja: Mahima Institute Indonesia.

Endraswara, S. (2013). Sosiologi Sastra: Studi, Teori, dan Interpretasi. Yogyakarta: Penerbit Ombak.

Glikberg \& Charles I. (1967). Literature and Society. Nederland: Martinus Nijhoff The Hague.

Luxemburg, J. J. H., Bal, M. G., Weststeijn, W. G., \& Hartoko, D. (1984). Pengantar Ilmu Sastra. Jakarta: Penerbit PT Gramedia.

Nurgiyantoro, B. (1995). Teori Pengkajian Fiksi. Yogyakarta: Gajah Mada University Press.

Nurgiyantoro, B. (2010). Teori Pengkajian Sastra. Yogyakarta: Gajah Mada University Press.

Putra, I. N. D. (2011). Tonggak Baru Sastra Bali Modern. Denpasar: Pustaka Larasan.

Ratna, N. K. (2008). Teori, Metode, dan Teknik Penelitian Sastra. Yogyakarta: Pustaka Pelajar. Cetakan IV.

Ratna, N. K. (2011). Paradigma Sosiologi Sastra. Yogyakarta: Pustaka Pelajar.

Suardiana, I. W. (2011). Crita Manyrita Sajeroning Kasusastraan Bali Purwa. Denpasar: Cakra Press.

Sudaryanto. (1993). Metode dan Aneka Teknik Analisis Bahasa (Pengantar Penelitian Wahana Kebudayaan Secara Linguistis). Yogyakarta: Duta Wacana University Press.
Sukarini, N. W. (2015). Aspek-Aspek Sosial Cerpen Magibung, Paras Paros, Dan Cerpen Sarwagita Dalam Kumpulan Cerpen Sawelas Satua Bawak Basa Bali. Jurnal Humanis, 11(3).

Tarigan, H. G. (1984). Prinsip-Prinsip Dasar Sastra. Bandung: Angkasa.

Wellek, R., \& Warren, A. (1990). Teori Kesusastraan, Terjemahan Melani Budianta. Jakarta: Gramedia. 